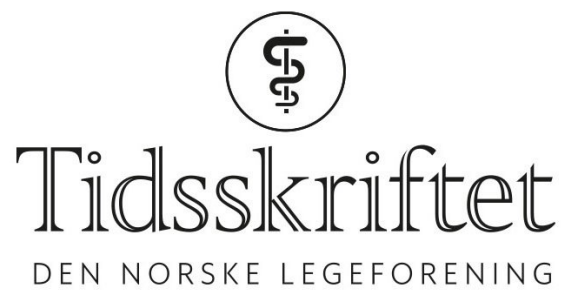

\title{
Diabetesmedisin mot Parkinsons sykdom
}

FRA ANDRE TIDSSKRIFTER

ØYVIND STOPLE SIVERTSEN

Tidsskriftet

Eksenatid, som er en GLP-1-hemmer mot diabetes, letter symptomene og har en mulig nevroprotektiv effekt ved Parkinsons sykdom. Det viser en ny studie.

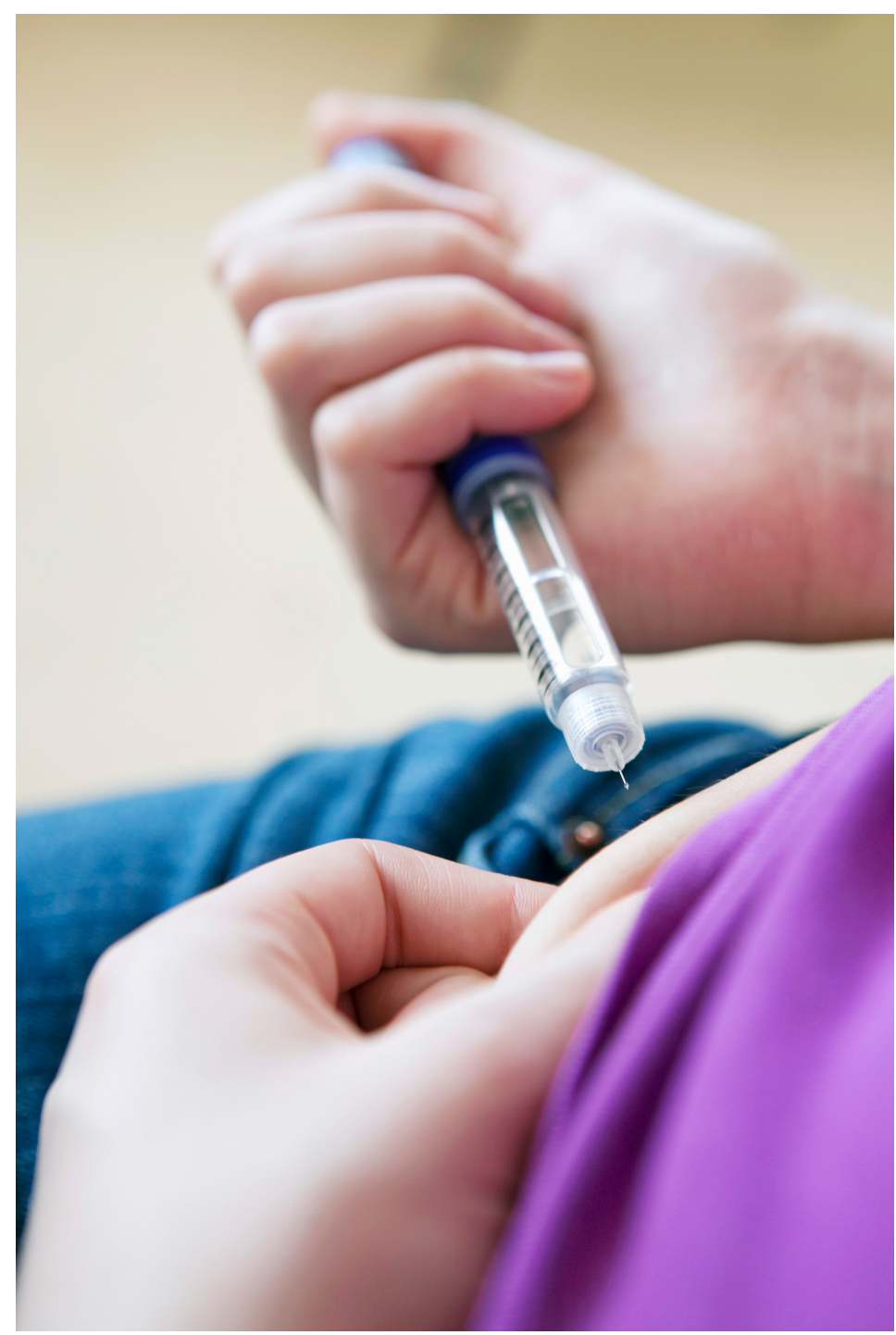

Illustrasjonsfoto: Science Photo Library / B. Boissonnet 
Hypotesen om at antidiabetiske medikamenter kan virke beskyttende mot Parkinsons sykdom er ikke ny. I en studie som nylig er publisert i The Lancet har forskere ved University College of London vist at behandling med GLP-1-hemmeren eksenatid har positiv symptomatisk effekt og en mulig nevroprotektiv virkning hos pasienter med Parkinsons $\operatorname{sykdom}(1)$.

Subkutane injeksjoner med eksenatid eller placebo ble gitt én gang ukentlig i 48 uker til 62 pasienter. Etter en 12 uker lang venteperiode ble symptomer og kliniske funn vurdert med et validert skåringsskjema. Det var forskjell mellom gruppene i deler av denne testen, spesielt der man undersøkte motorikken.

- Dette er meget interessante funn, som er i tråd med tidligere funn i studier av en annen klasse antidiabetiske midler - glitazoner. Likevel har vi foreløpig ikke tilstrekkelig kunnskap til å begrunne bruk av antidiabetika hos pasienter med Parkinson sykdom, sier Charalampos Tzoulis, som er overlege i nevrologi og forskningsleder ved Haukeland universitetssykehus.

- Den symptomatiske effekten i denne studien er ikke bedre enn den som kan oppnås med dagens behandling, slik som dopaminerstattende behandling. Den nevroprotektive effekten er også usikker, sier han.

- Det viktigste ved denne og lignende studier er at de identifiserer energimetabolismen og glukosehomøostasen som mulige sykdomsmekanismer ved Parkinsons sykdom, og at det kan tenkes at disse kan påvirkes i terapeutisk sammenheng, sier Tzoulis, som ser frem til forskning for å kartlegge de nøyaktige mekanismene bak de observerte effektene.

\section{LITTERATUR:}

1. Athauda D, Maclagan K, Skene SS et al. Exenatide once weekly versus placebo in Parkinson's disease: a randomised, double-blind, placebo-controlled trial. Lancet 2017;390: 1664 - 75. [PubMed][CrossRef]

Publisert: 12. desember 2017. Tidsskr Nor Legeforen. DOI:10.4045/tidsskr.17.0931

(C) Tidsskrift for Den norske legeforening 2020. Lastet ned fra tidsskriftet.no 